Article

\title{
Housing Vienna: The Socio-Spatial Effects of Inclusionary and Exclusionary Mechanisms of Housing Provision
}

\author{
Michael Friesenecker * and Yuri Kazepov \\ yuri.kazepov@univie.ac.at (Y.K.) \\ * Corresponding author \\ Submitted: 15 November 2020 | Accepted: 8 February 2021 | Published: 13 May 2021
}

Department of Sociology, University of Vienna, 1090 Vienna, Austria; E-Mails: michael.friesenecker@univie.ac.at (M.F.),

\begin{abstract}
The provision of housing plays a decisive role in segregation processes. In a European context increasingly influenced by variegated neo-liberal housing policies, Vienna's approach is characterised by generous access to social housing. This inclusive strategy aims at actively preventing segregation and the isolation of certain groups. Over the last 30 years, however, reconfigured multi-level arrangements and wider contextual changes have transformed Vienna's housing governance. This article explores how. In particular, it aims at disentangling the relationship between housing policy reforms at multiple policy levels and the changes of the mechanisms shaping the access to tenure segments and residential segregation in Vienna. Through the use of process tracing, we identify critical junctures of housing governance and relate them to housing segmentation and segregation measures over a period of approximately 30 years. Our findings show that reforms on multiple levels produce an increasingly deregulated private rental market and an increasingly fragmented access to a diversified provision of social housing. From a spatial point of view, persistent patterns of segregation blend with new ones, leading to decreasing segregation characterised by a more even spatial distribution of low and high-status groups. At the same time, both groups show very low, but slightly increased levels of isolation. Tenant profiles in social housing are, however, generally still very mixed. Balancing the trade-off between a social mix and social targeting without excluding residents in need will remain the main challenge for Vienna's social housing model.
\end{abstract}

\section{Keywords}

housing access; housing policy; inclusion; multi-level governance; segregation; social mix; Vienna

\section{Issue}

This article is part of the issue "Vicious Circle of Segregation: Understanding the Connectedness of Spatial Inequality across Generations and Life Domains" edited by Tiit Tammaru (University of Tartu, Estonia), Siiri Silm (University of Tartu, Estonia), Frank Witlox (Ghent University, Belgium), Maarten van Ham (Delft University of Technology, The Netherlands) and Madli-Johanna Maidla (University of Tartu, Estonia).

(C) 2021 by the authors; licensee Cogitatio (Lisbon, Portugal). This article is licensed under a Creative Commons Attribution 4.0 International License (CC BY).

\section{Introduction}

In the context of globalisation, neoliberalisation and welfare state retrenchments, increasing social inequalities and segregation levels are well documented in urban areas worldwide but to varying degrees (Musterd, 2020, p. 415). For Europe, recent research has shown that the process of residential segregation differs across countries and cities because of an interplay of various factors. According to Tammaru, Marcińczak, van Ham, and
Musterd (2016), at least four factors interact in shaping segregation: (1) globalisation and economic restructuring, (2) social inequalities, (3) welfare regimes and (4) housing regimes. Yet these factors are not fully accountable in explaining the differences in segregation that led Musterd, Marcińczak, van Ham, and Tammaru (2017) to conclude that local contexts and path-dependent urbanisation patterns may (partially) override the structural factors.

In that regard, the role of (local) housing policies, modes of housing provision and tenure structure shape 
the spatial distribution of tenure segments and the socio-spatial outcomes of economic restructuring and social inequality in urban settings (Andersen, Andersson, Wessel, \& Vilkama, 2016; Arbaci, 2019; Maloutas, 2012). Maloutas (2012, p. 10) emphasised that the "shifting and sorting of housing allocation processes" are central filters in translating the household's unequal financial resources into socio-spatial inequalities. This financial capacity shapes "preferences, opportunities and restrictions," whereas opportunities and restrictions also depend on housing stock availability and (institutional) allocation mechanisms (van Ham \& Manley, 2014, p. 253). From this perspective, housing segmentation based on different qualities and allocation mechanisms, as well as the size and balance of different housing tenures, are considered important in channelling the uneven/even distribution of social groups across housing tenures and space (Andersen et al., 2016; Arbaci, 2019; Giffinger, 1998; Murie \& Musterd, 1996).

However, neoliberal housing policy ideas in which housing became increasingly perceived as a commodity rather than a public responsibility emerged (Wetzstein, 2017). The promotion of owner-occupation, re-commodification, privatisation and, residualisation of social housing, reduction of brick-and-mortar subsidies in favour of person-oriented subsidies and the deregulation of rent controls are some examples (Arbaci, 2019; Kadi \& Musterd, 2014; Scanlon, Whitehead, \& Fernández Arrigoitia, 2014). Nevertheless, the State continues to play a key role in regulating housing, mediating the pace, impact and form of these policies producing "diversified responses at the national and local level" (Maloutas, Siatitsa, \& Balampanidis, 2020, p. 6).

In Amsterdam, for instance, the promotion of the owner-occupation sector has weakened the function of a large and high-quality public rental sector, but its significant size enables the public sector to house the middle classes leading to less marked social separation in space (Musterd, 2014). Another example with different outcomes is Stockholm. The national government and later the City of Stockholm enabled the conversion of public housing units to market-based cooperatives, which led to substantial gentrification of inner-city areas and higher levels of segregation (Andersson \& Turner, 2014). Other countries such as France and Austria preserved and even enhanced the social housing sector, yet the 'social' orientation among those countries became increasingly fragmented (Lévy-Vroelant, Reinprecht, Robertson, \& Wassenberg, 2014). Reports from Southern European cities show that low levels of segregation have increased since the 1990s, as the familistic model of homeownership, characterised by self-production and informal access to land, was increasingly replaced by a credit financed access to homeownership (Arbaci, 2019; Maloutas, 2012). Social rental sectors in Central and Eastern European cities are highly fragmented as national social housing stocks have been largely privatised and the existing stock became residualised and often decen- tralised to municipalities (Hegedüs, Lux, Sunega, \& Teller, 2014). In some cities, this initially led to decreasing segregation levels through emerging suburbanisation and gentrification processes, which was interpreted as a paradox of (post)socialist segregation (Marcińczak, Gentile, \& Stępniak, 2013). However, recent evidence suggests that this trend is temporary and is followed by increasing segregation tendencies in the second decade after the fall of state socialism (cf. Kovács, 2020).

Against this background, this article focuses on the housing policy trajectory of Vienna and traces policy reforms since the 1980s concerning housing segmentation and residential segregation. In the European context, Vienna is portrayed as a unitary housing regime characterised by a large social housing stock, which roots in nearly a century-long political hegemony of the social democratic party. Vienna's housing policy followed and still aims to follow an egalitarian 'housing for all' approach, which provides social housing to a broad section of society to actively reduce social segregation and the isolation of certain groups. Yet, changing multi-level configurations and housing reforms at different levels altered housing provision as well as the access to different housing segments. The aim of this article is, therefore, to explore the relationship between housing policies at multiple policy levels, and local changes in housing segmentation and residential segregation in Vienna since the 1980s. More specifically, we seek to understand the relation between changing housing segmentation, accessibility and levels and patterns of socioeconomic segregation. In particular, the extent to which Vienna was able to retain its inclusive and socially mixed approach to housing.

Research on Vienna has largely focused on ethnic segregation and housing market barriers for immigrant groups (Giffinger, 1998; Kohlbacher \& Reeger, 2020), but also on the socio-economic dimension (Hatz, 2009; Hatz, Kohlbacher, \& Reeger, 2016). Although these studies take into account the housing dimension, there has been no systematic analysis of housing reforms at multiple levels and its relation to tenure segmentation and segregation in the last 30 years. Furthermore, these studies focus mainly on 'evenness' and pay less attention to 'exposure,' which in our understanding captures the Viennese housing approach more precisely. We, therefore, follow a definition of residential segregation that emphasises the changing isolation or separation of one group from the rest of the population (cf. Johnston, Poulsen, \& Forrest, 2014, p. 16). A prime focus of segregation studies has been on 'evenness' (Massey \& Denton, 1988; Reardon \& O'Sullivan, 2004), a dimension usually operationalised as the over- and underrepresentation of certain groups across the neighbourhoods relative to their overall proportions of a city. However, as uneven patterns of over- and underrepresentation do not necessarily translate into stronger isolation of groups (Johnston et al., 2014), we additionally consider 'exposure.' This dimension refers to the likelihood that members of 
one group will encounter residents of a different background in their respective neighbourhoods (Reardon \& O'Sullivan, 2004).

To address these issues, the article proceeds as follows: In the next section (2) we lay out our analytical framework which emphasises the relationship between housing-welfare regimes, tenure segments and residential segregation in multi-level arrangements. This is followed by a methods section ( 3 ) describing the quantitative and qualitative approaches and data used. The next section (4) presents the most important critical junctures and housing reforms at multiple policy levels impacting Vienna's housing provision. Section five (5) will focus on changes in accessibility to housing segments concerning socio-economic trends, followed by (6) the analysis of changing levels and patterns of segregation. Finally, the conclusion (7) will discuss what we can learn from Vienna's housing trajectory on processes of housing segmentation and segregation.

\section{Housing Regimes between Path Dependency, Reforms and Multilevel Arrangements}

The relation between housing policy, housing tenure and segregation from a comparative perspective has mostly relied on the concepts of dualist and unitary housing regimes (Kemeny, 1995). Recently, this approach has been further developed into "housing-welfare regimes" to emphasise the close connection of housing and broader welfare regimes (cf. Stephens, 2020, p. 523). The most comprehensive account between housing regimes and segregation is, to our knowledge, the work of Arbaci (2019). Beyond the redistributive effects of housing tenure compositions, she demonstrated that forms of housing production and promotion, ownership and regulation of land supply and the profit regime shape the segregation patterns. She found that in relation to segregation, liberal welfare cities tend to be associated with higher levels of segregation because of their large-scale, market-oriented housing context that produces a dualised tenure structure dominated by owneroccupation, as opposed to a residualised social housing sector (Arbaci, 2019, pp. 78-90). The least segregated cities are associated with corporatist regimes, because of their mixed-scale housing provision characterised by a balanced (unitary) tenure structure with a predominance of the private rental sector. Between these two extremes, the familistic welfare cluster (of Southern Europe), dominated by small-scale, owneroccupied housing provision, produces less segregated cities, whereas social-democratic welfare regimes and their associated large-scale and dominant social housing production is characterised by higher levels of segregation (Arbaci, 2019, p. 88).

As housing-welfare regimes are changing in light of recent policy reforms (Stephens, 2020), tenure restructurings and changes in housing segmentation are important analytical elements in understanding the chang- ing redistributive role of housing, also concerning segregation. Housing segmentation can be understood as a process in which housing provision is segmented into different forms of tenure characterised by "different qualities and conditions for access" (Andersen et al., 2016, p. 3). These qualities and conditions are highly dependent on the type of housing provision and the allocation mechanisms of the operating market-state nexus. As processes, they crucially shape uneven or even 'socio-tenurial differentiation' (Arbaci, 2019) or 'sociotenurial polarisation' (Murie \& Musterd, 1996). On the one hand, housing inequality is thus shaped by mainly market-based inclusionary and exclusionary mechanisms that enable or restrict opportunities on the housing market based on the household's financial resources (Maloutas, 2012; van Ham \& Manley, 2014). On the other hand, these market-based inclusionary and exclusionary mechanisms may be reinforced-or mitigated-by housing policies.

Housing policies might regulate the 'price' of housing through rent regulation. Rent regulation may be applied to certain segments only (e.g., according to the age of the building) or the whole rental market (Kadi, 2015; Kadi \& Musterd, 2014). With regard to the deregulation of rent, no clear-cut picture across Europe can be depicted. However, what the study of Kettunen and Ruonavaara (2020) shows is that it makes an important difference if the initial rent and rent increases are controlled or if only rent increases are controlled. Nevertheless, de-regulation of rent-control most likely impacts the inclusionary/exclusionary mechanisms to housing segments, for instance, by raising (financial) access barriers to low-income residents on the private rental market (Kadi, 2015; Kadi \& Musterd, 2014). Housing segmentation might be also channelled through additional (non-monetary) access and eligibility criteria or discriminatory housing allocation practices (Maloutas, 2012). Knijn and Akkan (2020, p. 225) consider decisions on the deservingness of vulnerable groups, which are grounded in criteria of equity and needs, as central mechanisms of inclusion and exclusion. In relation to social housing in the UK, van Ham and Manley (2014) argue that needs-based systems were designed to bring objectivity into housing allocation processes. However, it must be assumed that the interplay of inclusionary and exclusionary mechanisms based on eligibility criteria and the diminishing social housing stock leads to limited redistributive options for those in need. Yet, much depends on the demand as well as the availability and size of the (social) housing stock.

Another important analytical element in translating socio-tenurial differences into residential segregation is the spatial distribution of the housing segments. The diminishing relevance of social housing and its concentration in certain parts of the city clearly leads to increased levels of segregation and the residualisation of low-status residents in social housing (Tammaru et al., 2016). The point here is that the socio-spatial 
impacts of (changing) housing regimes might still be mediated by urbanisation patterns of cities, differences in the structure of the economy, cultural differences, and more nuanced and complex institutional arrangements (van Kempen \& Murie, 2009). In relation to institutional arrangements, for instance, Bengtsson and Ruonavaara (2011) have shown that crucial differences within the seemingly uniform Nordic Housing Regime exist and that they are shaped by path-dependent actors' arrangements.

For these reasons, it becomes increasingly important to focus on multi-level institutional arrangements to allow for a more thorough understanding of the changing distributive effects of housing-welfare systems and changing levels and patterns of segregation (Arbaci, 2019). Stephens (2020) argues that the theory on housing regimes needs to engage more in-depth with the role of institutions, both at the very local level and upper-tier levels. From this perspective, research should focus on how the access to housing segments is regulated and how local policy choices unfold concerning supra-national and global financial mechanisms, such as the European Union's financial policy. Such a multilevel focus enables us to attune our attention to the trajectories of city-specific political choices, forms of governance and planning practices in housing both shaped by path-dependencies and impacts of higher-tier policies. In general, according to Maloutas et al. (2020, p. 6) such "genealogies and path-dependencies of national and local housing systems" allow not only a deeper understanding of the effects but also to identify institutional changes and new housing policies that deepen housing exclusion. Following this, we conceptualise cities as embedded in wider (multi-level) institutional relations and contexts (Kazepov, 2005) to analyse the city's redistributive capacities (Fainstein, 2010).

\section{Research Approach, Methods and Data}

We started our investigation by analysing policy reforms that led to a reconfiguration of housing provision. In doing so, we used the method of process tracing, which allows identifying the policy shifts that (1) influenced the mode of housing provision and (2) affected the housing segmentation and accessibility of housing segments, hence how inclusionary and exclusionary mechanisms changed over the last three decades. This allowed us not only to detect critical junctures or pathchanging events but also to trace them back to changing contextual factors and policy reforms at different levels. Following Bengtsson and Ruonavaara (2011), our analysis focused on important political decisions regarding tenure legislation, access to different housing segments and the specific contextual factors that led to policy choices. As contextual factors, we considered important events which changed the political frame for action (e.g., EU membership). The process-tracing method draws on evidence from the analysis of regulatory and policy docu- ments and grey literature. In a second step, expert interviews with local and national policy-makers and officials responsible for housing policy were held to validate the identified critical junctures and the impacts of multi-level arrangements and contextual factors.

We then analysed the relation between housing policy reforms and housing segmentation as well as residential segregation. In doing so, we analysed changing tenure profiles based on educational attainment and unemployment for different housing segments in order to relate shifts in accessibility. Due to the paucity of historic individual microdata, this analysis is limited to 2005 and 2018. To analyse the relation to segregation we calculated a) the well-known dissimilarity index representing 'evenness' and b) the modified index of isolation representing 'exposure.' Both indices allow for international comparison (Tammaru et al., 2016) and allow for longitudinal comparison as they account for changes in group size, which is most likely when considering longer study periods (Johnston et al., 2014). We calculated these indicators for the years 1991, 2001, 2011 and 2017 based on around 1.350 statistical areas, which are the smallest available statistical units for Vienna. To reveal changing patterns of segregation in terms of an even or clustered distribution of social groups in space (Reardon \& O'Sullivan, 2004), we also deployed a spatial clustering method using the Local Moran's I (see Anselin, 1995). In doing so, we used a low-status composite indicator which considered: (1) the share of the low-educated population, (2) the unemployment rate and (3) the share of the working class including unqualified manual workers and routine service and sales workers. To take into account the overall changes of social groups in the city, the mean value of the standardised locational quotients was first calculated for each year, followed by a Moran's I analysis using the mean of the locational quotients. The spatial dependence was modelled using a spatial weight matrix taking into account the thirty nearest statistical areas. The suitability of the weight matrix was approved by a robustness check of the spatial weight matrix. This check largely confirmed that, with both low and high numbers of nearest neighbours, persistent spatial patterns and levels of clustering exist.

\section{Vienna's Housing Policy between Persistence and Change}

Vienna's long history of promoting socially inclusive forms of housing provision can be traced back to the era of 'Red Vienna' when around 60,000 municipal housing estates were built from 1920 to 1934 (cf. Kadi \& Suitner, 2019). Already from this early phase, most municipal housing was built in the form of 'superblocks' (Blau, 2014). Access to this early form of municipal housing privileged skilled workers, municipal servants and lowskilled employees but was also oriented along social needs criteria, which not necessarily focused on the poor (Lévy-Vroelant et al., 2014). In the 1950s, Vienna's 
municipal housing provision continued its communal housing program following the logic of a universalist or 'housing for all' approach mostly financed via reconstruction funds. As the Social Democratic Party has been in charge of the most influential administrative units managing housing since the end of World War II, the underlying orientation of the City's social-democratic housing model to achieve social equity and prevent social segregation has remained in place until today.

In the 1950s, however, Vienna's housing provision also got more embedded into the national housing system which forms the basis of today's multi-level framework in housing policy (Matznetter, 2002). This period was marked by the introduction of the housing subsidy legislation in 1954, which became an important cornerstone of Austria's housing policy. In 1989, housing subsidies have been increasingly decentralised to the Bundesländer, such as Vienna, which is both a Bundesland and a municipality of the Federal Republic of Austria. This decentralisation gave the City of Vienna more power in subsidising housing provision and urban renewal through which the City can overrule two important federal laws temporarily: the Tenancy Law and the Limited-Profit Housing Act.

The applicability of different types of rent regulation of the federal Tenancy Law depends mainly on the buildings' year of construction and the date of the rental contract. As a rule of thumb, buildings built before 1945 are rent-level controlled, albeit in different ways according to the date of contract (see details below), while for the other rental stock, regulations regarding contract termination and duration are in place. The resurrection of the German Non-Profit Law, which became the Limited-Profit Housing Act in 1978, paved the way for limited-profit housing associations (LPHAs) as additional key providers of social housing. Regulated at the national level, these actors of the third sector are considered as social housing providers as they are allowed to charge cost-covering rents only. Additionally, in exchange for tax exemptions, their economic field of action is limited to housing reinvestments. Bundes/änder only have the power to permit LPHAs as housing providers in their regions.

Before presenting the first critical juncture of Vienna's recent housing policy trajectory, we want to highlight the City's context of the 1980s. The City saw the main urban challenges in overcrowded innercity housing and an increasing spatial concentration of immigrants in the substandard housing stock built before World War I. As a reaction to population decline through increased suburbanisation, the city focused on the qualitative upgrading of this housing stock. In doing so, it introduced the 'soft urban renewal' program in the mid-1980s and established a 'renewal and land fund' that is today known as the wohnfonds_wien (see Figure 1). Focusing on the pre-war, mainly private rental housing stock in central locations, the 'soft urban renewal' model is realised through public-private partnerships. This approach aims at subsidised renovations that raise the quality of private rental apartments while preserving the historic housing stock without displacing people, by freezing the rent levels for 10 years (Hatz et al., 2016; Kadi, 2015).

A first important critical juncture was the Fall of the Soviet Union in 1989, which brought about increased immigration in the early 1990s. Political parties aimed at countering the resulting housing shortage, which became a pressing issue in Vienna. Initially-with an amendment to the tenant law at the federal level-they introduced time-limited contracts in 1991. The Social Democrats accepted the introduction of time-limited contracts as a temporal solution to raise housing supply since the law foresaw a $20 \%$ discount on the rent level. More substantial was the amendment to the tenant law of 1994, which introduced a quasi-market mechanism to buildings constructed before 1944 and rental contracts signed after 1994 more significantly. Old contracts remain well protected and their rent control is based on housing quality categories (reference value rent). For new rental contracts, landlords could raise rents according to specific premiums, for example, location premiums in specific areas (Kadi, 2015). In general, these reforms undermined the redistributive capacities of Vienna's socially oriented housing policy as the housing allocation mechanism in the regulated private rental market became increasingly marketbased. Additionally, the conservative/right-wing government pursued its neo-liberal housing policy at the federal level and excluded tenancy in detached and semidetached houses and attic conversions in 2001. This led to a somewhat paradoxical situation that attic conversions on rent-controlled buildings in inner-city neighbourhoods become free-market rent, while the rest of the buildings are still rent-controlled. In general, the latter deregulations undermined the City's housing approach which increasingly aimed at providing additional, affordable housing in the inner-city districts by attic conversions.

A second critical juncture was Austria's accession to the European Union, which influenced the social housing provision of Vienna in various ways. Although construction levels were already low in the 1990s, the withdrawal of municipal housing construction in 2004 must be seen from this perspective. In fact, the Social-DemocratsVienna's ruling party-justified this decision by arguing that they had to comply to the budgetary constraints implied by the Maastricht criteria and state aid regulations of the European Union's competition law. Despite this development, the City kept its municipal housing stock characterised by the lowest rents across all tenures. The public housing stock was neither converted nor privatised, as some other European cities did to varying degrees, for example, Stockholm or London. Furthermore, as the construction of subsidised social housing by LPHAs already outweighed the construction of municipal housing in the 1990s, the administration argued that rent levels in newly built subsidised social 


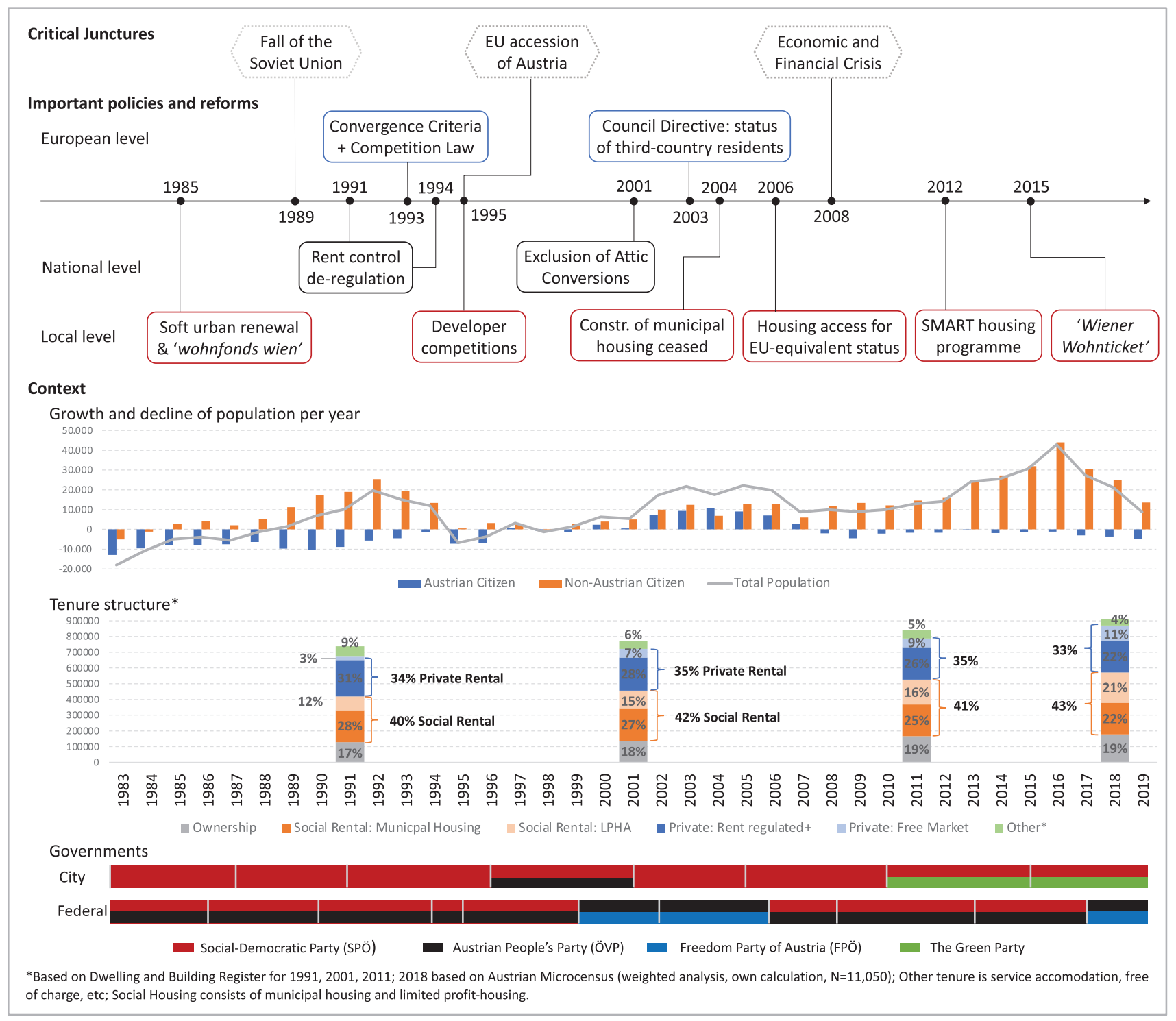

Figure 1. Important critical junctures, housing policies and contextual data. Source: Authors' own calculations based on data from STATcube-Statistische Datenbank von Statistik Austria, Statistik Austria and the Microcensus 2018.

housing provided by LPHAs were similar. Hence, as of 2004, Vienna solely relied on subsidised social housing provision, built via subsidising mainly LPHAs. This approach builds on two path-dependent elements of Austria's housing policies. First, on the federal LimitedProfit Housing Act and its reliance on cost-based rents and, second, on the decentralisation of housing subsidies to the federal states in 1989. By linking housing subsidies with land allocation policies and developer competitions, the City continued its universalistic housing approach mainly by steering housing provision. The city-owned land fund established in 1985 (wohnfonds_wien) which started to buy up land in close relationship to urban development zones at the outskirts since the mid-1980s, additionally became the main responsible body to organise social housing provision via developer competitions during the 1990s. The City, however, retained its power to set the (social) criteria for developer competi- tions since the head of the fund is the City Counsellor for Housing.

The adaption of Vienna's social housing policy approach enabled the City to provide new social housing. Although the City grew dramatically by 380,000 residents between 1991 and 2018, this approach was able to stabilise the tenure structure. Social rental housing maintained its dominant position in Vienna's unitary housing regime followed by private rental and a less important home-ownership sector (see Figure 1). However, beyond these main tenure segments, a rather uneven tenure restructuring occurred. While LPHAs nearly doubled in relative terms and clearly compensated for the stagnation of municipal housing, the rent-regulated private rental sector became less important. This led to a higher amount of insecure rental contracts and freemarket rents, especially in inner-city areas characterised by the pre-war housing stock. As a consequence of this 
uneven restructuring in sub-segments, the inclusionary and exclusionary mechanism of Vienna's housing system was reconfigured along access, housing security and housing price developments in line with changing socioeconomic contexts.

\section{Accessibility of Housing Segments: Reconfiguring Inclusionary and Exclusionary Mechanisms}

The context for shifts in inclusionary and exclusionary mechanisms of Vienna's housing regime is mainly related to a steep population and educational expansion as well as rising vulnerability. According to Verwiebe, Haindorfer, Dorner, Liedl, and Riederer (2020), the atrisk-of-poverty rate increased since 1995 by 7 percentage points, whereas unemployment has almost doubled since the 1990 s (10\% in 2018) and nearly two-thirds of people at risk of poverty were unemployed in 2018. Furthermore, their study revealed that the most pronounced difference in unemployment emerges between natives and people with first- and second-generation migratory backgrounds. Barriers to labour market integration and increased vulnerabilities are very much tied to the uneven growth patterns of educational levels as well as economic restructuring. Between 1991 and 2017, Vienna witnessed a massive increase of residents with tertiary education $(+220,000)$, whereas residents with compulsory education declined $(-50,000)$. Both groups account for about 23\% in 2017.

In interplay with this changing socio-economic context, the approach characterising access to social housing (e.g., targeted at middle-income groups) began to change with the ceasing of municipal housing construction. In general, income thresholds to access social housing are relatively high $(47,740 €$ annual net-income for one person, 71,130€ for two persons in 2021), around two times higher than those in Berlin for instance, so that about eighty percent of Viennese are 'theoreticalIy' eligible (Marquardt \& Glaser, 2020, p. 8). A Viennese peculiarity in social housing provision is tenant contributions for land and construction costs of social housing production (Lévy-Vroelant et al., 2014). These contributions were used to co-finance the construction costs for the historical municipal housing from the 1960 s onwards, wheras the current provision of new subsidised social housing mainly built by limited-profit housing makes use of tenant contributions for construction and land costs. As housing subsidies do not cover all construction and land costs, tenants need to pay contributions in the form of one-time payments when moving into social housing. These tenant contributions are capped at $500 € / \mathrm{m}^{2}$ and work as a quasi-loan that will be paid back to the tenants when moving out, with one percent depreciation per year from the original sum (cf. Marquardt \& Glaser, 2020, p. 7).

Against this peculliarity, the shift from constructing municipal housing to subsidising social housing had two important effects in terms of access to the social hous- ing sector. First, to access municipal housing, tenants do not need to pay tenant contributions anymore, which contributed to the inclusiveness of low-income and vulnerable groups. Second, the tenants' contributions for new subsidised social housing mainly built by LPHAs became a problematic barrier to low-skilled and vulnerable groups. This shift in accessibility is confirmed by the development of tenant profiles for the most important rental segments compared to all main residencies between 2005 and 2018 (see Figure 2). The tenants' composition in municipal housing saw an increase of lowskilled as well as unemployed residents while retaining a wide social mix. On the contrary, the tenants' profile for LPHAs remains persistently exclusionary for low-skilled and vulnerable groups.

This exclusionary mechanism became further intensified as affordable land for new social housing became scarce because of increased construction activities by the private sector, which led to increased tenant contributions during the 2000s (Kadi, 2015). However, becoming increasingly aware of this access barrier, the City started to introduce caps on tenant contributions in developer competitions, which were later mainstreamed into the SMART housing program (see Figure 1). Since 2012, it has become a common practice that one-third of all apartments in new subsidised social housing need to be planned as SMART apartments. These apartments are intentionally smaller in size but receive higher subsidies and caps on tenant contributions apply. Additionally, the capped tenant contributions may be financed by means-tested loans from the City (Marquardt \& Glaser, 2020, p. 7). This clearly enhanced the inclusion of lowerincome residents into subsidised limited profit housing and shows the power of the City of Vienna in shaping the social orientation of social housing.

An equally important housing reform that is rooted in Austria's accession to the EU was the council's 2003 directive concerning the long-term residency of third-country nationals. From 1993 to 2006, eligibility to municipal housing was granted to legally-aged Austrian citizens with a one-year residence in Vienna and an income below the above-mentioned threshold. Additionally, needs-based criteria such as overcrowding or health are applied. The EU-directive opened access to social housing for EU/EEA citizens and third-country citizens of equal status in 2006. To achieve equal status, a residence permit can be granted both to third-country citizens after five years of permanent main residency or to recognised refugees. Furthermore, the reform of the centralised allocation system to social housing saw the introduction of the Wiener Wohnticket in 2015, which fragmented eligibility to the increasingly differentiated social housing stock. While the main eligibility criteria were maintained, the city extended exclusionary barriers for (foreign) newcomers to municipal housing providing a bonus in the ranking to long-term Viennese residents. Second, needs-based criteria for municipal housing and SMART apartments were further diversified: 


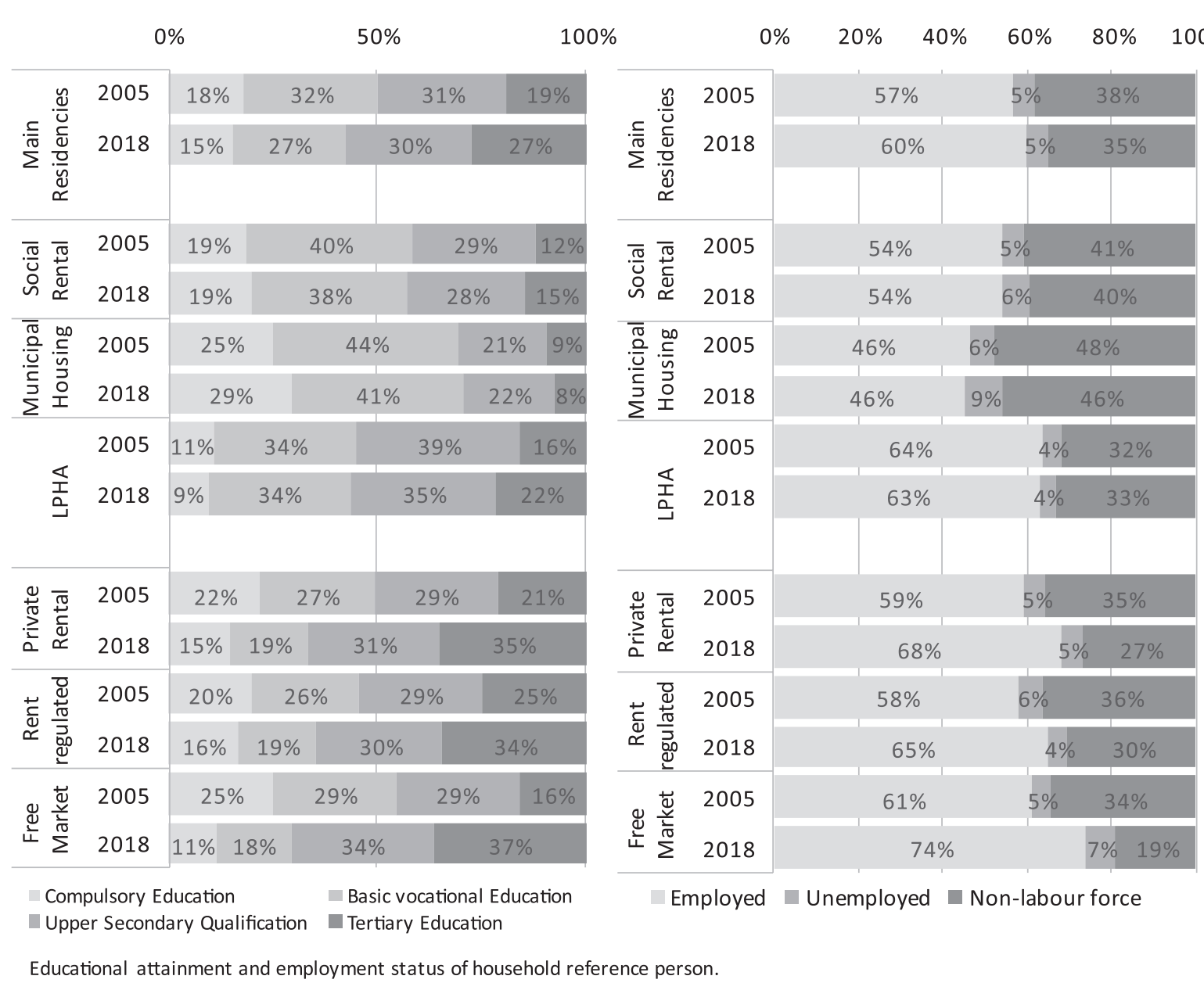

Figure 2. Tenant profiles for housing segments, Vienna 2005-2018. Source: Authors' own calculations based on Statistik Austria and the Microcensus 2005, 2011, 2018.

Besides overcrowding, people in need of barrier-free apartments, specific needs of elderly and younger residents were acknowledged. Third, the allocation process for subsidised social housing became rather complex as two-thirds of regularly subsidised apartments and half of the SMART apartments can be allocated directly by LPHAs without additional needs-based criteria, whereas the rest of the regularly subsidised apartments are allocated by the City of Vienna.

In sum, the interplay of financial, eligibility-based and needs-based criteria shows that Vienna used its 'historic' municipal housing stock for an increasing shift towards the inclusion of low-skilled and vulnerable groups for municipal housing (see Figure 2). Yet, their recent reforms have also produced exclusions, especially for low-income newcomers in need or homeless persons that cannot fulfil the criteria of the main residency (cf. Kadi, 2015). However, quotas for emergency apartments for social hardship cases exist, as well as specific programmes and social services for housing homeless and refugees (Reinprecht, 2014). Although this led to a drop in ethnic segregation (Kohlbacher \& Reeger, 2020), our tenant profile analysis shows that municipal housing witnessed an increase of Non-Austrian citizens, even though most non-Austrian citizens are dependent on the private rental market. There, especially low-income and low-skilled newcomers increasingly face affordability issues. On the contrary, the newly subsidised housing retained its middle-class orientation, mainly because of tenant contributions.

As for the private rental segment, market-based mechanisms became more important after increasing renewal activities and the deregulation of rent control: time-limited contracts and locational premiums. These apartments are concentrated in the central districts (see Figure 4) and especially newcomers to Vienna face increasing rental prices in these locations. Kadi's (2015) study revealed that locational premiums remained rather stable until the Global Economic and Financial Crisis and increased dramatically thereafter. This third critical juncture (see Figure 1 ) shows that after the crisis, financialisation of housing took a stronger halt in Vienna and-in interplay with the deregulation of rent control-contributed to steep increases in (private) rents, housing and land prices (Aigner, 2020). Bearing that in mind, tenants' profiles for private rental and its submarkets in Figure 2 reveal that low-skilled groups are increasingly excluded from these segments. This is supported by other evidence on increasing housing cost burdens for low-income newcomers (Kadi, 2015). 


\section{Trends of Levels and Patterns of Segregation}

Having outlined the relationship between changing multilevel arrangements and changes in Vienna's housing landscape, we now turn to analyse these changes concerning levels and patterns of segregation vis-á-vis the spatial distribution of housing segments. With regard to 'evenness,' our analysis confirms that the rather uneven distribution of high-status and low-status groups across the city has decreased. Compared to London, segregation is slightly lower in Vienna but slightly higher than in Amsterdam, where segregation decreased during the 2000s, and similar to Stockholm, where segregation has increased dramatically because of cutbacks on housing subsidies and public housing privatisation (Tammaru et al., 2016). The drop of the dissimilarity index from 42 to 38 (Figure 3 ) is mirrored by trends towards a more dispersed distribution of high-status and low-status groups across the city.

In the 1990s, Vienna's segregation pattern was dominated by an overrepresentation of high-status groups in the Western outskirts characterised by single-family houses and cottages and in the city centre dominated by a small-scaled, pre-war multi-storey housing stock of higher quality (Figure 4, left, green coloured clusters), while low-status groups are overrepresented following a doughnut shape around the northern, western and southern Gürtel (Figure 4, brown clusters). These areas are characterised by a mix of low-quality, pre-war housing on small building lots to large social housing estates. Until 2017, segregation-in the form of (un)even distribution of group clusters around the city-decreased as clusters of high-status and low-status groups became more dispersed throughout the city. Additional clusters of high-status groups were identified in the eastern outskirts and the cluster in the city centre started to expand in 1991 throughout almost all inner-city districts between the Ring and the Gürtel. Clusters of low-status groups expanded towards north-eastern and southern parts of the outer districts between 2001 and 2011.

The most significant drop of the dissimilarity index was measured between 1991 and 2001. This most likely relates back to the effects of the urban renewal efforts from the 1980s onwards, when the pre-war housing stock of inner-city areas was renovated. In interplay with the immigration of a high-skilled workforce and associated lifestyle changes, an increasing social upgrading of inner-city areas took place (cf. Hatz, 2009). However, the expansion of clusters of high-status residents in the inner-city areas in subsequent periods tends to be closer related to rising rent costs triggered by the deregulations of rent control at the national level and increased financialisation of housing (cf. Kadi, 2015). Inner-city areas, therefore, became increasingly

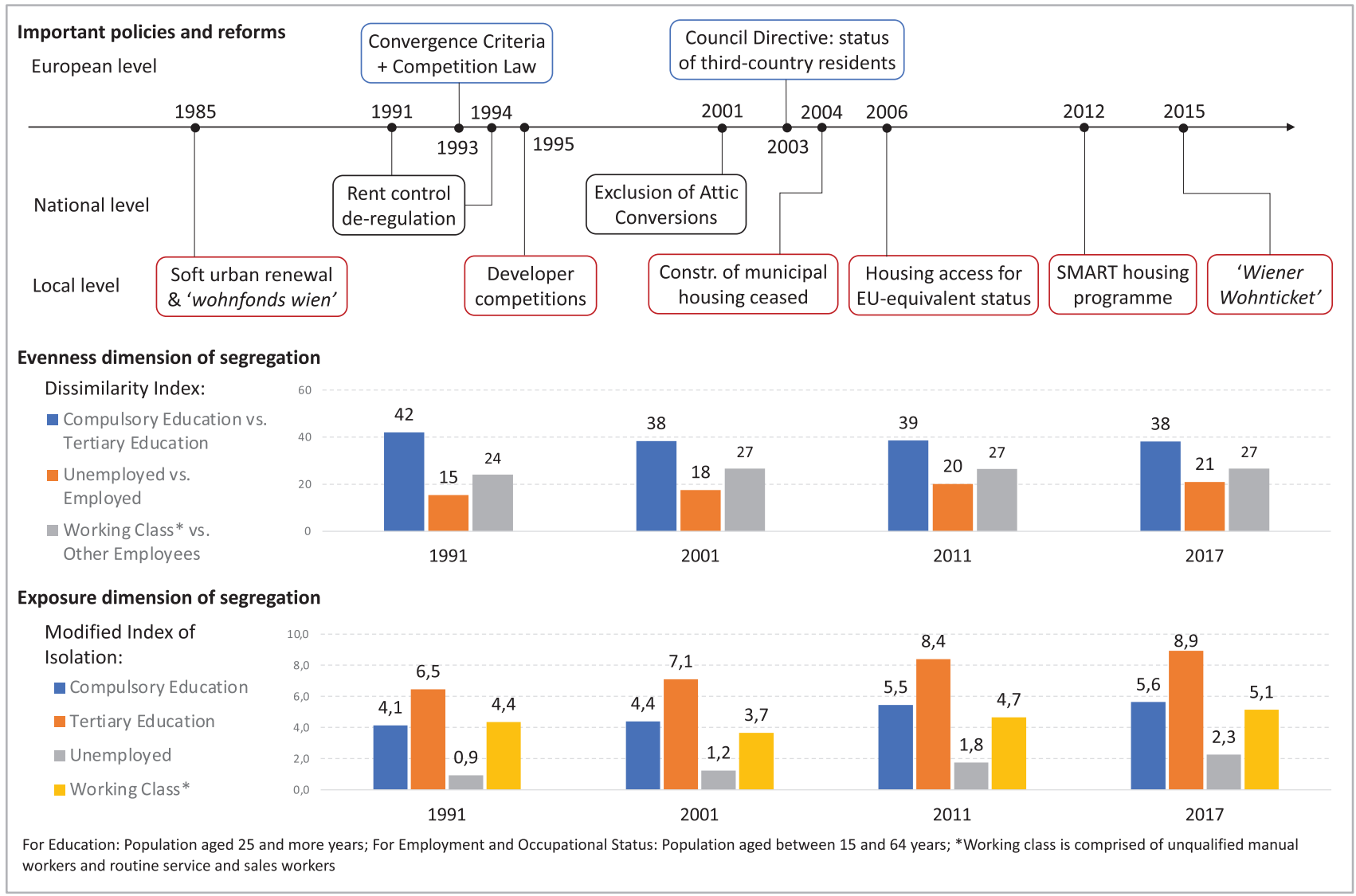

Figure 3. Important housing policies and segregation. Source: Authors' own calculations based on MA23-Wirtschaft, Arbeit und Statistik. 
inaccessible for low-status and economically marginalised groups, fuelling gentrification tendencies (Hatz et al., 2016). However, one would expect a further increase in segregation levels due to the introduction of marketbased mechanisms, but the expansion of low-status groups from 2001 onwards towards the north-eastern and southern parts of the city seem to work against this trend. As a consequence, segregation, measured as the dissimilarity index between high- and low-status groups, remained stable.

Expanding concentrations of low-status groups are related to the distribution of large municipal housing

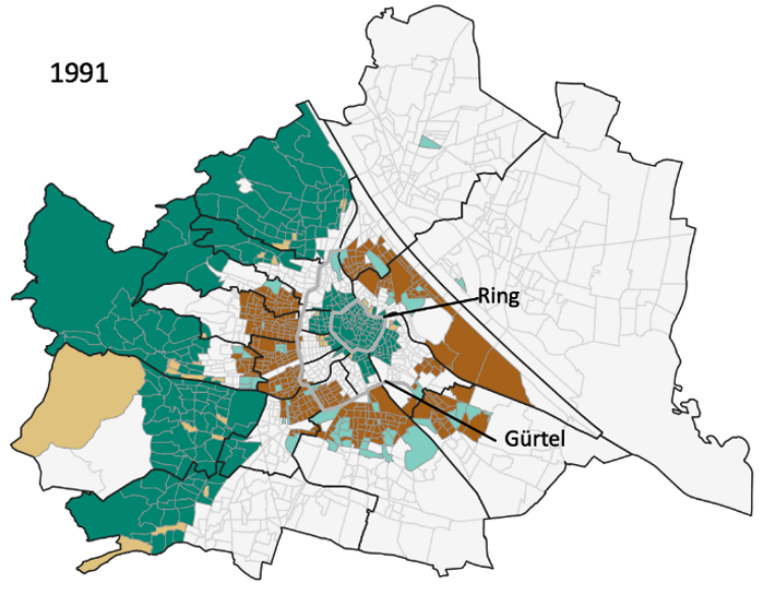

Local Moran I Clusters (significant at 0.001) $\square$ Not Significant

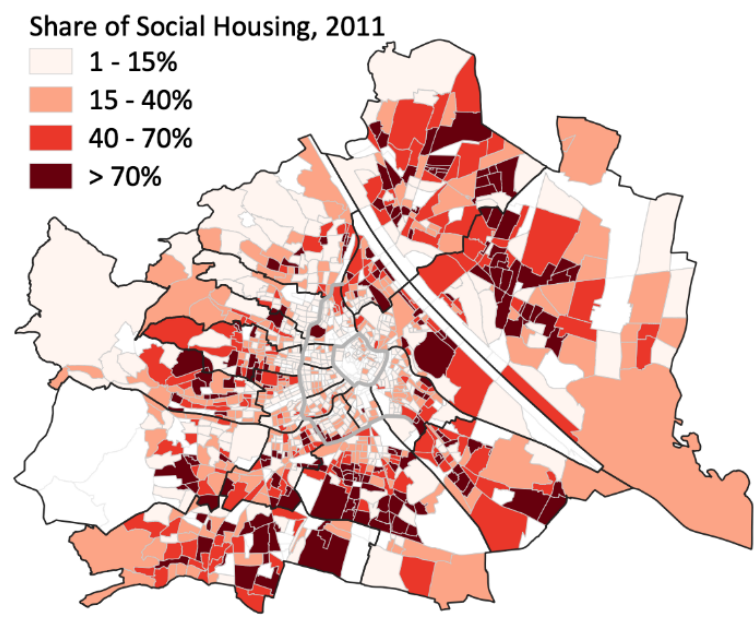

Share of Substandard Apartments, 2011



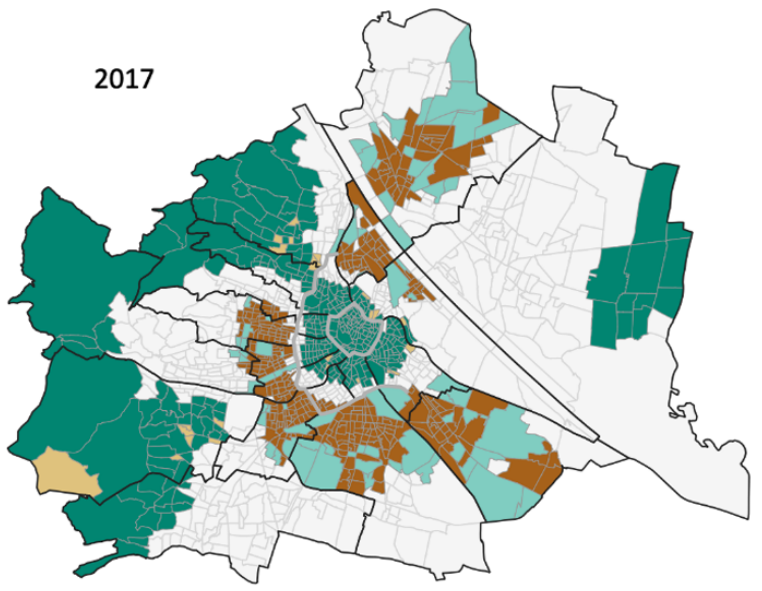

Cluster of Low-Status Groups $\square$ Low-High Cluster of High-Status Groups $\square$ High-Low

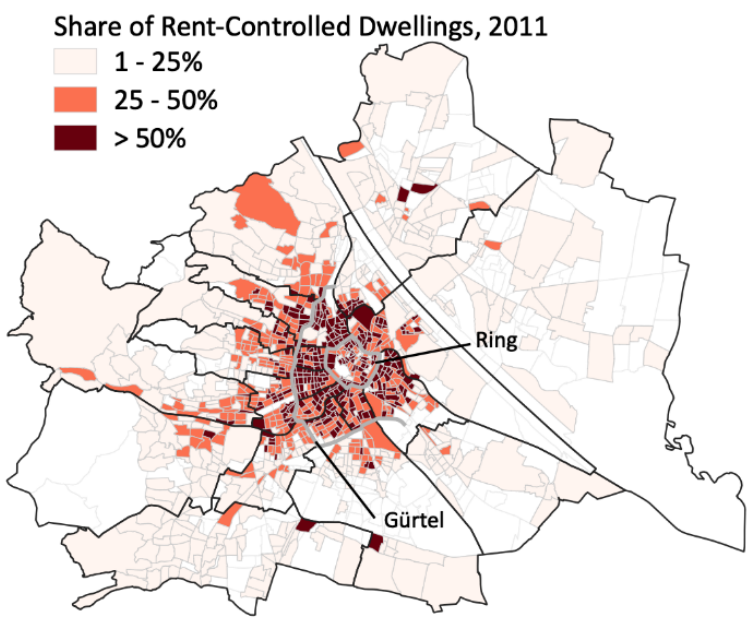

Share of Home- and Apartmentownership, 2011

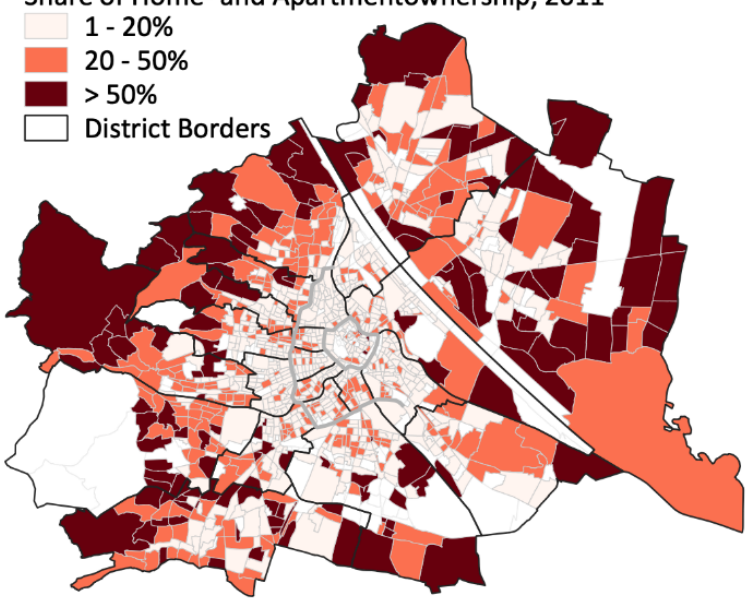

Figure 4. Cluster map of low status composite indicator from 1991 and 2017 (top) and the spatial distribution of housing segments in 2011 (bottom). Source: Authors' own calculations based on MA23-Wirtschaft, Arbeit und Statistik. 
estates from the post-war era (1950-1980) and can be interpreted as the spatial effect of shifts in tenant profiles shown in the previous section. Although the introduction of needs-based criteria and a stronger social targeting of municipal housing brought greater inclusion of low-skilled and vulnerable groups but decreases the social mix. At least, for the clusters in the northern and south-eastern parts presented in Figure 4, a residualisation is rather likely. The overrepresentation of low-status groups around the western and southern parts of the Gürtel with its low-quality private rental has remained since 1991. As found in other studies (Hatz et al., 2016), this persistence confirms the importance of substandard private rental as arrival spaces for low-skilled newcomers and can be read as the spatial effects of the (increasingly tight) access criteria to social housing. In fact, although barriers to social housing based on citizenship have been removed, low turnover rates and growing demand for social housing explain long waiting lists and the spatial consequences.

The two spatial trends described above are coherent with the paradoxical effects reported in other cities. First, segregation patterns between high and low-status groups can decrease when gentrification processes are still at work (Musterd, 2020, p. 418). Our results confirm the argumentation by Musterd et al. (2017) that both Vienna and Amsterdam are characterised by similar processes-such as ongoing gentrification processes. Second, the "paradoxical effect of welfarism" (Andersen, 2012, p. 195), in which marginalised groups are supported but also segregated through the provision of large, modernist social housing estates, became more articulated in Vienna. The path-dependent egalitarian approach of Vienna's social housing policies that aimed at a social mix seems to be at a turning point since the mid-2000s. Concerning the 'exposure' dimension of segregation, the very low levels of isolation shown in Figure 3 underline that Vienna is still a socially mixed city. There is indeed a high probability of encountering groups with a different socio-economic background at the neighbourhood level. Nevertheless, the increase of the indices suggests the slightly stronger isolation of low-skilled, unemployed and working-class from higher-status groups (Figure 3 ). An important finding, however, is that the increase in isolation of lower-status groups is less marked than for those of higher-status. The aim of the egalitarian 'housing for all' approach to limit social segregation mitigates the outcomes of the City's housing market restructuring. Especially, the large number of municipal housing stock and the newly subsidised social housing slow down the changing levels of isolation for lower-status groups, even though in some areas, in which social housing plays a dominant role, this is likely to be the case.

\section{Conclusion}

This article has set out to analyse the relation between trends and patterns of segregation in Vienna and the reconfiguration of inclusionary and exclusionary mechanisms emerging from recent multi-level housing policy reforms since the 1990s. In analysing the recent genealogy of Vienna's housing regime, we aimed at understanding to which degree Vienna is challenged to maintain its inclusive and socially mixed housing approach. In doing so, we analysed the policy developments at multiple levels using a process-tracing method focusing on changing modes of housing provision and regulation. In particular, we considered the changing access criteria and the resulting housing distribution for different tenure segments. These mechanisms were then analysed with regard to changing tenant profiles as well as changing patterns and levels of segregation.

The results of our study resonate with the increasing literature on context-bounded paradoxes of segregation processes (Arbaci, 2019; Marcińczak et al., 2013; Musterd et al., 2017). In particular, our findings suggest that the decreasing levels of segregation between highstatus and low-status groups relate to two processes. On the one hand to the expanding gentrification tendencies in central districts (Marcińczak et al., 2013; Musterd et al., 2017). On the other hand, to emerging patterns of residualisation in some parts of the City characterized by large municipal housing estates. The latter process relates to the paradox of welfarism, in which increasing support produces segregated outcomes in contexts characterised by large social housing estates (Andersen, 2012, p. 195). Hence, our analysis provides evidence that decreasing levels of segregation in terms of even and uneven distribution of social groups across space are driven by two mechanisms that work against each other. This relatively mild polarisation trend is underpinned by the fact that levels of isolation are still very low, even though they have slightly increased for both higher-status and lower-status groups.

Our analysis has also provided evidence that the above-mentioned segregation paradoxes relate to recent shifts in housing policies at multiple policy levels along three contextual junctures: (1) the fall of the Soviet Union, (2) Austria's accession to the EU and (3) the global economic and financial crisis of 2008. While the fall of the Soviet Union and its associated population growth set the path for the deregulation of rent control at the national level, increased investments in housing after the economic and financial crisis have deepened marketisation efforts and exclusionary tendencies on the private rental market, especially in central locations marked by high-quality housing. Neoliberal policy reforms mainly imposed from upper-tier levels, therefore, paved the way for greater marketisation on Vienna's private rental and ownership segments.

Moreover, Vienna's social housing provision, and especially the access to social housing, became increasingly fragmented because of financial, eligibility-based and needs-based criteria. This changing role relates to Austria's accession to the EU. On the one hand, EU policies have contributed to pushing Vienna's social housing 
approach towards the path of a more targeted municipal housing sector. The still particularly large stock of municipal housing has become more inclusionary for low-status and vulnerable groups, and upon pressures from the EU was also opened to third-country citizens of EU equivalent status. However, emerging residualisation trends are observable. Yet, the residualisation of the social housing sector appears to be limited in comparison to highly dualised housing regimes. While clusters of low-status groups in large municipal housing estates exist, tenant profiles for the whole sector suggest that the social mix is still largely in place. Pockets of greater residualisation and isolation most likely exist concerning scale and conditions of the municipal housing premises. However, concerning that, our study is limited and calls for micro-scale studies to explore potential trade-offs between inclusiveness, residualisation and emerging stigmatisation.

Nevertheless, the turn towards subsidising social housing-provided mostly through limited profit housing-allowed Vienna to 'actively' maintain its socialdemocratic, unitary housing regime. In particular, it sustained redistributive capacities to offer permanent rental contracts at below-market rents, opposing neo-liberal tendencies in the private rental market for a broad section of the society. In 2019 about 780,000 out of 1.86 million inhabitants lived in municipal and limited-profit housing (Statistik Austria, 2020). Yet, this comes with trade-offs as subsidised social housing rather caters to mid-income classes. While this contributes to a wellbalanced social mix, it does so at the expense of excluding low-income households. Balancing the trade-off between a social mix and social targeting without excluding residents in need will remain the main challenge for Vienna's social housing context (see also Marquardt \& Glaser, 2020). Recent efforts to raise the inclusiveness for lower-income residents in subsidised social housing and the resumption of municipal housing construction (Kohlbacher \& Reeger, 2020, p. 111) are promising and much-needed signals to mitigate ongoing neoliberal pressures in the private rental market.

\section{Acknowledgments}

We would like to thank the editors of this thematic issue and the anonymous reviewers for their helpful comments. This research was supported by the Austrian Science Fund (FWF) under the project "Vienna in Transition. (Dis-)Continuities of Urban Change in a European City" (Project Number: P 30617). We kindly thank Katharina Litschauer for her contribution to data collection.

\section{Conflict of Interests}

The authors declare no conflict of interests.

\section{References}

Aigner, A. (2020). What's wrong with investment apartments? On the construction of a 'financialized' rental investment product in Vienna. Housing Studies. Advance online publication. https://doi.org/ 10.1080/02673037.2020.1806992

Andersen, H. T. (2012). The solidity of urban socio-spatial structures in Copenhagen. In T. Maloutas \& K. Fujita (Eds.), Residential segregation in comparative perspective: Making sense of contextual diversity (pp. 177-198). Farnham: Ashgate.

Andersen, H. S., Andersson, R., Wessel, T., \& Vilkama, K. (2016). The impact of housing policies and housing markets on ethnic spatial segregation: Comparing the capital cities of four Nordic welfare states. International Journal of Housing Policy, 16(1), 1-30.

Andersson, R., \& Turner, L. M. (2014). Segregation, gentrification, and residualisation: From public housing to market-driven housing allocation in inner city Stockholm. International Journal of Housing Policy, 14(1), 3-29.

Anselin, L. (1995). Local indicators of spatial associationLISA. Geographical Analysis, 27(2), 93-115.

Arbaci, S. (2019). Paradoxes of segregation: Housing systems, welfare regimes and ethnic residential change in Southern European cities. Oxford: John Wiley \& Sons.

Bengtsson, B., \& Ruonavaara, H. (2011). Comparative process tracing in housing studies. International Journal of Housing Policy, 11(4), 395-414.

Blau, E. (2014). From red superblock to green megastructure: Municipal socialism as model and challenge. In M. Swenarton, T. Avermaete, \& D. van den Heuvel (Eds.), Architecture and the welfare state (pp. 27-50). Abingdon: Routledge.

Fainstein, S. S. (2010). The just city. Ithaca, NY: Cornell University Press.

Giffinger, R. (1998). Segregation in Vienna: Impacts of market barriers and rent regulations. Urban Studies, 35(10), 1791-1812.

Hatz, G. (2009). Features and dynamics of socio-spatial differentiation in Vienna and the Vienna Metropolitan Region. Tijdschrift voor economische en sociale geografie, 100(4), 485-501.

Hatz, G., Kohlbacher, J., \& Reeger, U. (2016). Socioeconomic segregation in Vienna: A social-oriented approach to urban planning and housing. In T. Tammaru, S. Marcińczak, M. van Ham, \& S. Musterd (Eds.), Socio-economic segregation in European capital cities. East meets West (pp. 80-109). London and New York, NY: Routledge.

Hegedüs, J., Lux, M., Sunega, P., \& Teller, N. (2014). Social housing in post-socialist countries. In K. Scanlon, C. Whitehead, \& M. Fernández Arrigoitia (Eds.), Social housing in Europe (pp. 239-253). Oxford: John Wiley $\&$ Sons. 
Johnston, R., Poulsen, M., \& Forrest, J. (2014). Segregation matters, measurement matters. In C. D. Lloyd, I. G. Shuttleworth, \& D. W. Wong (Eds.), Social-spatial segregation: Concepts, processes and outcomes (pp. 13-44). Bristol: Policy Press.

Kadi, J. (2015). Recommodifying housing in formerly "Red" Vienna? Housing, Theory and Society, 32(3), 247-265.

Kadi, J., \& Musterd, S. (2014). Housing for the poor in a neo-liberalising just city: Still affordable, but increasingly inaccessible. Tijdschrift voor economische en sociale geografie, 106(3), 246-262.

Kadi, J., \& Suitner, J. (2019). Red Vienna, 1919-1934. In A. M. Orum (Ed.), The Wiley Blackwell encyclopedia of urban and regional studies (pp. 1-5). Hoboken, NJ: Wiley-Blackwell.

Kazepov, Y. (2005). Cities of Europe: Changing contexts, local arrangements, and the challenge to social cohesion. In Y. Kazepov (Ed.), Cities of Europe: Changing contexts, local arrangements, and the challenge to social cohesion (pp. 3-42). Oxford: Blackwell Publishing.

Kemeny, J. (1995). From public housing social market. Rental policy strategies in comparative perspective. London and New York, NY: Routledge.

Kettunen, H., \& Ruonavaara, H. (2020). Rent regulation in 21st century Europe. Comparative perspectives. Housing Studies. Advance online publication. https:// doi.org/10.1080/02673037.2020.1769564

Knijn, T., \& Akkan, B. (2020). Mechanisms that impede justice. In T. Knijn \& D. Lepianka (Eds.), Justice and vulnerability in Europe (pp. 214-232). Cheltenham: Edward Elgar Publishing.

Kohlbacher, J., \& Reeger, U. (2020). Globalization, immigration and ethnic diversity: The exceptional case of Vienna. In S. Musterd (Ed.), Handbook of urban segregation (pp. 101-117). Cheltenham: Edward Elgar Publishing.

Kovács, Z. (2020). Do market forces reduce segregation? The controversies of post-socialist urban regions of Central and Eastern Europe. In S. Musterd (Ed.), Handbook of urban segregation (pp. 118-133). Cheltenham: Edward Elgar Publishing.

Lévy-Vroelant, C., Reinprecht, C., Robertson, D., \& Wassenberg, F. (2014). Learning from history: Path dependency and change in the social housing sectors of Austria, France, the Netherlands and Scotland, 1889-2016. In K. Scanlon, C. Whitehead, \& M. Fernández Arrigoitia (Eds.), Social housing in Europe (pp. 277-296). Oxford: John Wiley \& Sons.

Maloutas, T. (2012). Introduction: Residential segregation in context. In T. Maloutas \& K. Fujita (Eds.), Residential segregation in comparative perspective: Making sense of contextual diversity (pp. 1-36). Farnham: Ashgate.

Maloutas, T., Siatitsa, D., \& Balampanidis, D. (2020). Access to housing and social inclusion in a postcrisis era: Contextualizing recent trends in the city of
Athens. Social Inclusion, 8(3), 5-15.

Marcińczak, S., Gentile, M., \& Stępniak, M. (2013). Paradoxes of (post) socialist segregation: Metropolitan sociospatial divisions under socialism and after in Poland. Urban Geography, 34(3), 327-352.

Marquardt, S., \& Glaser, D. (2020). How much state and how much market? Comparing social housing in Berlin and Vienna. German Politics. Advance online publication. https://doi.org/10.1080/09644008. 2020.1771696

Massey, D. S., \& Denton, N. A. (1988). The dimensions of residential segregation. Social Forces, 67(2), 281-315.

Matznetter, W. (2002). Social housing policy in a conservative welfare state: Austria as an example. Urban Studies, 39(2), 265-282.

Murie, A., \& Musterd, S. (1996). Social segregation, housing tenure and social change in Dutch cities in the late 1980s. Urban Studies, 33(3), 495-516.

Musterd, S. (2014). Public housing for whom? Experiences in an era of mature neo-liberalism: The Netherlands and Amsterdam. Housing Studies, 29(4), 467-484.

Musterd, S. (2020). Towards further understanding of urban segregation. In S. Musterd (Ed.), Handbook of urban segregation (pp. 411-424). Cheltenham: Edward Elgar Publishing.

Musterd, S., Marcińczak, S., van Ham, M., \& Tammaru, T. (2017). Socioeconomic segregation in European capital cities. Increasing separation between poor and rich. Urban Geography, 38(7), 1062-1083.

Reardon, S. F., \& O'Sullivan, D. (2004). Measures of spatial segregation. Sociological Methodology, 34(1), 121-162.

Reinprecht, C. (2014). Social housing in Austria. In K. Scanlon, C. Whitehead, \& M. Fernández Arrigoitia (Eds.), Social housing in Europe (pp. 61-73). Oxford: John Wiley \& Sons.

Scanlon, K., Whitehead, C., \& Fernández Arrigoitia, M. (2014). (Eds.), Social housing in Europe. Oxford: John Wiley \& Sons.

Statistik Austria. (2020). Wohnen 2019. MikrozensusWohnungserhebung und EU-SILC [Housing 2019. Microcensus-Housing survey and EU-SILC]. Statistik Austria. Retrieved from http://www.statistik. at/wcm/idc/idcplg?IdcService=GET_PDF_FILE\& dDocName $=123361$

Stephens, M. (2020). How housing systems are changing and why: A critique of Kemeny's theory of housing regimes. Housing, Theory and Society, 37(5), 521-547.

Tammaru, T., Marcińczak, S., van Ham, M., \& Musterd, S. (Eds.). (2016). Socio-economic segregation in European capital cities: East meets West. London and New York, NY: Routledge.

van Ham, M., \& Manley, D. (2014). Segregation, choice based letting and social housing: How housing policy can affect the segregation process. In C. D. Lloyd, I. 
G. Shuttleworth, \& D. W. Wong (Eds.), Social-spatial segregation: Concepts, processes and outcomes (pp. 247-268). Bristol: Policy Press.

van Kempen, R., \& Murie, A. (2009). The new divided city: Changing patterns in European cities. Tijdschrift voor economische en sociale geografie, 100(4), 377-398.

Verwiebe, R., Haindorfer, R., Dorner, J., Liedl, B., \&
Riederer, B. (2020). Lebensqualität in einer wachsenden Stadt: Endbericht an die Stadt Wien [Quality of life in a growing city: Final report to the City of Vienna]. Vienna: Department of Sociology, University of Vienna.

Wetzstein, S. (2017). The global urban housing affordability crisis. Urban Studies, 54(14), 3159-3177.

\section{About the Authors}

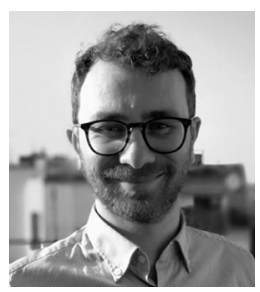

Michael Friesenecker is a Research Assistant at the Department of Sociology, University of Vienna. Before that, he worked as a research assistant at the Department of Geography, University of Vienna, where he is currently a PhD candidate. Broadly speaking, his work focuses on multi-scalar and comparative perspectives on urban transformations. From these perspectives, his recent research centres around urban (development) policies, neighbourhood revitalisation, gentrification and the social and spatial implications of housing and environmental policies.

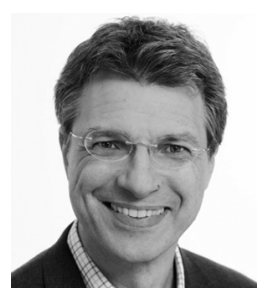

Yuri Kazepov is Professor for International Urban Sociology and Compared Welfare Systems at the Department of Sociology, University of Vienna. He is a founding member of the Network for European Social Policy Analysis (ESPAnet) and former president of RC21. His fields of interest are urban governance, citizenship and urban quality of life, social policies in comparative perspective. He investigates the European city within multilevel governance systems as an analytical rhetorical device to understand differences in comparative terms. 